\title{
Article \\ Communities of Practice in the Warlpiri Triangle: Four Decades of Crafting Ideological and Implementational Spaces for Teaching in and of Warlpiri Language
}

\author{
Emma Browne ${ }^{1, *(\mathbb{D})}$ and Fiona Gibson Napaljarri ${ }^{2}$ \\ 1 School of Literature, Languages and Linguistics, Australian National University, \\ Canberra, ACT 0200, Australia \\ 2 Warlpiri Education Training Trust (WETT), Nyirrpi, NT 0872, Australia; fnapaljarri@gmail.com \\ * Correspondence: Emma.browne@anu.edu.au
}

Citation: Browne, Emma, and Fiona Gibson Napaljarri. 2021.

Communities of Practice in the Warlpiri Triangle: Four Decades of Crafting Ideological and

Implementational Spaces for

Teaching in and of Warlpiri Language. Languages 6: 68. https://doi.org/ 10.3390/languages6020068

Academic Editors: Elisabeth Mayer, Carmel O'Shannessy and Jane Simpson

Received: 25 January 2021

Accepted: 22 March 2021

Published: 6 April 2021

Publisher's Note: MDPI stays neutral with regard to jurisdictional claims in published maps and institutional affiliations.

Copyright: (C) 2021 by the authors Licensee MDPI, Basel, Switzerland. This article is an open access article distributed under the terms and conditions of the Creative Commons Attribution (CC BY) license (https:// creativecommons.org/licenses/by/ $4.0 /)$.

\begin{abstract}
Warlpiri communities in Australia's Northern Territory (NT) have long advocated for the inclusion of Warlpiri language, values and knowledge in their government-run schools. After the first bilingual programs were established in the NT in the 1970s, educators and community members from four Warlpiri communities formed a professional network known as the Warlpiri Triangle, a platform for meetings and professional development focusing on teaching and learning in and of Warlpiri language in schools. On these platforms, educators have consistently articulated the goal of the Warlpiri programs as maintenance of Warlpiri pirrjirdi, 'strong Warlpiri language'. In this paper we seek to explore the development, refinement and consolidation of a consensual ideology around teaching and learning of and in Warlpiri pirrjirdi, 'strong Warlpiri language' that has informed Warlpiri language-in-education management. We analyse interviews with five Warlpiri educators at Yuendumu school in 2018/9 and a body of grey literature from four decades of Warlpiri educator professional development activities that has been less widely acknowledged and visible in local education policy discourse. We draw on the theoretical concept of communities of practice to understand the ways in which Warlpiri educators negotiate ideological and implementational spaces for inclusion of Warlpiri language teaching in the context of an ambivalent language-ineducation policy environment. The results of this study exemplify the reiteration and reproduction of language-in-education goals through a community of practice in a sustained arena of action, the Warlpiri Triangle. The findings render more visible the vital efforts of Warlpiri educators and their professional networks in shaping language-in-education policy and practice to realise community aspirations of Warlpiri language maintenance in the school context.
\end{abstract}

Keywords: Warlpiri; endangered languages; language maintenance; language ideologies; languagein- education management; language-in-education policy; minority language education; Aboriginal educators; first language teaching; Australia

\section{Introduction}

"We've been showing our commitment to education for decades now"

(Patterson and Anderson 2014)

Throughout the history of formal education of Indigenous children in the Northern Territory (NT), Indigenous communities have continued to advocate for recognition and inclusion of their languages, cultures and identities in order to maintain linguistic and cultural knowledges, access the curriculum, foster wellbeing and as a means for taking an active role in the education of their children (Anderson et al. 2018; Bat and Shore 2013; Disbray and Martin 2018; Lee et al. 2014; Marika et al. 2009; McMahon and Murray 1999; Simpson et al. 2009; Simpson and Wigglesworth 2008; Warlpiri-patu-kurlangu-jaru 2011). The comment in the epigraph by Warlpiri educators speaking at the Garma Festival in 2014 
encapsulates the long history of Indigenous community involvement in the governmentrun education system. For the past four decades, educators across four remote Warlpiri communities in Australia's Tanami desert have collectively and collaboratively engaged in bottom-up language-in-education policy, planning and management to articulate their goals for first language education in a bilingual model involving Warlpiri and English in their schools. Over the decades, the overt government support for these bilingual programs and for first language teaching and learning has varied, but the commitment of Warlpiri communities has been unwavering (Devlin 2009; Disbray 2015; Disbray and Martin 2018; Disbray et al. 2020a; Minutjukur et al. 2014; Nicholls 2005; Purdie et al. 2008; Ross and Baarda 2017).

Over this 40-year period, changes have been documented in the local language ecologies as a result of contact with English, and linguistic and cultural survival in the midst of a dominant English-speaking Australian society are critical concerns for many Warlpiri today (Bavin and Shopen 1985; O'Shannessy 2012; O'Shannessy 2019, 2020b). Warlpiri communities have consistently expressed the goal of maintaining Warlpiri pirrjirdi, 'strong Warlpiri language' in schools, characterized by Warlpiri void of mixing or borrowing from English (Bilingual Resource Development Unit 1987; Martin and Oldfield 2000; Northern Territory Department of Education 2008). This raises questions of how Warlpiri pirrjirdi 'strong Warlpiri' is constructed and positioned for teaching and learning in the context of diverse and dynamic community language practices. How are educators' ideological engagements with classroom language use conceptualized and what strategies have been collaboratively developed to achieve this in schools?

In this paper, the authors, a Warlpiri educator and a non-Warlpiri researcher, collaborate to explore the consistent articulation of language maintenance goals among Warlpiri educators during professional development activities over four decades. We examine, through document analysis and interviews with Warlpiri educators, the collective framing of local policies that drive the Warlpiri programs. We endeavour to render more visible the processes of developing a consensual ideology (Spolsky 2004) or what Kroskrity (2009) has called "ideological clarification" at Warlpiri schools, situated in a chequered macro-level policy environment (Devlin et al. 2017). We describe how these ideologies are expressed in the production of discourses around the construction of a preferred classroom code, Warlpiri pirrjirdi 'strong Warlpiri language'. We then identify three of the shared practices that educators have developed and refined to promote the use of Warlpiri pirrjirdi in the classroom which include (1) clear articulation of features of Warlpiri pirrjirdi 'strong Warlpiri language' and its conscious use in teaching, (2) collaborative practices with peers, mentors and community elders, and (3) engagement with Warlpiri texts as exemplars of Warlpiri pirrjirdi 'strong Warlpiri'. Ultimately our analysis demonstrates the power of communities of practice (Coburn and Stein 2006; Lave and Wenger 1991; Wenger 1998) for Warlpiri language teachers to open up "ideological and implementational spaces" (Hornberger 2002) for teaching and learning of, and in, Warlpiri language in Warlpiri schools.

\section{Theoretical Framing: Endangered Language Maintenance and Communities of Practice in Schools}

The role of schools in first language maintenance has been a contested topic in the literature on minority and endangered languages (Disbray 2015; Hirvonen 2008; May and Hill 2005; McCarty and Nicholas 2014; Spolsky and Hornberger 2008; Truscott and Malcolm 2010; Wyman et al. 2010). Research on language policy, planning and management in schools describes a complex, multilayered ideologically driven process, which engages numerous actors at multiple institutional layers from top-down government policy at the macro level, to regional and school level governance at the meso-level, and minority language representatives including teachers, families and students at the micro level (bottom-up) (Baldauf and Kaplan 2005; Cooper 1989). Ricento and Hornberger (1996) introduced the metaphor of the language policy and planning onion to highlight the multiple layers comprised of agents, levels and processes and to describe how they "permeate and interact with each other in a variety of ways and to varying degrees" (Ricento and Horn- 
berger 1996, p. 402) Within the field of language policy and planning, there is an interest in understanding how both structural forces and individuals' agency mediate language policy activities and processes (Hult 2010; Ricento 2000). The importance of bottom-up language planning in relation to heritage language resources has gained attention, and in recent decades the key role of language teachers in navigating language policy and shaping diverse classroom language practices has been recognized (Hornberger 2005; Menken and García 2010; Paciotto 2004, 2010; Palmer 2011; Palmer and Martínez 2013; Varghese 2008). These classroom language practices are locally defined and enacted within individual and wider ideological dimensions both internal and imposed in a complex interplay which Kroskrity (2018) has described as "language ideological assemblages".

The choices that teachers make about language education polices, programs and practices reflect ideological assumptions about languages, speakers, and their place in education. In minority language contexts, ideologies are inherently intertwined with language maintenance efforts involving value judgements about ways of speaking and processes of language change and shift under pressures from colonialism (Kroskrity 2005, 2018; Kroskrity and Field 2009; Makihara and Shieffelin 2007; Silverstein 1979). In viewing language preservation and renewal activities as sites for ideological struggles, Kroskrity (2009, p. 71) has argued for the importance of achieving "ideological clarification", aligning stated goals with less widely acknowledged but no less impactful beliefs, feelings and concerns. These struggles were first highlighted in seminal work of Hill, Jane, and Kenneth Hill (1986) in the context of Mexicano, and Dauenhauer and Dauenhauer (1998) in Tlingit, Haida and Tsimshian communities of Southeastern Alaska and more recently for Kaska (Meek 2007), White Mountain Apache (Nevins 2004), San Juan Paiute (Bunte 2009) and Rarámuri and Tarahumara (Paciotto 2004, 2010) among others.

Nancy Hornberger (2002, p. 30, emphasis mine) has posited the role of teachers as navigating, reinterpreting and appropriating policies for "opening up ideological and implementational space" (emphasis added) for endangered languages "to evolve and flourish rather than dwindle and disappear". The ideological spaces being the parameters and possibilities governing beliefs or feelings about languages in use, embedded in and shaped by political, economic interests within social settings. The implementational spaces, encompass teaching and learning practices, events and relations within the classroom and the wider community. Hornberger explains that the ideological and implementational spaces mediate and are mediated by each other, as the ideological spaces can inform implementational ones at classroom and community levels but also that implementational spaces can serve as wedges to open ideological ones (Hornberger 2005; Hornberger et al. 2006). Recent ethnographic work in this area, such as that of Hornberger and Johnson (2007); Menken and García (2010) and Marlow and Siekmann (2013) have offered rich descriptions of teachers' engagement with policy and the ways in which they can individually or collectively seize openings, and creatively and actively negotiate for space, transforming and expanding the possibilities for language education. Other research on educators' agency in the education system has drawn on the communities of practice perspective to illuminate the social processes involved (Aravossitas and Oikonomakou 2018; Borko 2004; Coburn and Stein 2006; Lave and Wenger 1991; Liu and Evans 2016; Marlow and Siekmann 2013; Wenger 1998). The term Community of Practice refers to a group of people who have developed shared practices, and historical and social resources (Lave and Wenger 1991). What holds such communities together is a common purpose, similar beliefs and value systems and collaboration, negotiation and elaboration to achieve consensus on and consistency of vision, goals and action. The strength of a professional learning community is formative in shaping ways that individual teachers engage with or depart from the official status quo (Coburn and Stein 2006; Gallucci 2003).

This paper contributes to language policy research which not only examines the role of policy in perpetuating mechanisms of exclusion, but also sheds light on educator agency in crafting spaces for linguistic inclusion (e.g., Johnson 2010; Marlow and Siekmann 2013). We seek to respond to calls by Lane et al. (2017) and Henne-Ochoa et al. (2020) for research 
that promotes Indigenous conceptions of language, what language maintenance means and how such conceptions shape and are shaped by language planning initiatives and practices in different social contexts. While the important role of dedicated community members and teachers in language revival and revitalization has been explored in contexts such as Hawaii (Brenzinger and Heinrich 2013) and New Zealand (McPake et al. 2017), much less is known about contexts where languages are still being spoken across all generations (Marlow and Siekmann 2013). We posit that understanding Warlpiri educators' engagement with ideology and implementation of language-in-education policy will inform broader questions of cultural and linguistic continuance and educational and linguistic justice in a language maintenance context (cf. McCarty and Nicholas 2014).

\section{Background to Warlpiri Communities and Education}

Warlpiri people traditionally lived a hunter-gatherer lifestyle in the Tanami Desert in the centre of the Australian continent. European exploration of the area is documented from the 1860s with sustained contact precipitated by the expansion of mining and pastoralism in the early twentieth century (Brown et al. 2011). The 1920s-30s was a period of intensified conflict over land and water compounded by prolonged drought and from the 1940s many Warlpiri shifted to reside in small remote settlements established by the governments as ration and welfare depots, now known as communities (for more on Warlpiri history and culture see Brown et al. 2011; Musharbash 2008). Four Warlpiri communities that include Yuendumu, Nyirrpi, Wirliyajarrayi (Willowra) and Lajamanu form what is known as the Warlpiri Triangle region (See Figure 1). Warlpiri diaspora also reside in the remote desert communities of Ti Tree and Alekarenge, as well as larger regional centres of Tennant Creek, Katherine, Alice Springs, Darwin and in major Australian cities (Burke 2018). Social relationships are extensive and there is an attitude of being 'one Warlpiri people' across the Warlpiri Triangle communities (Disbray et al. 2020a).

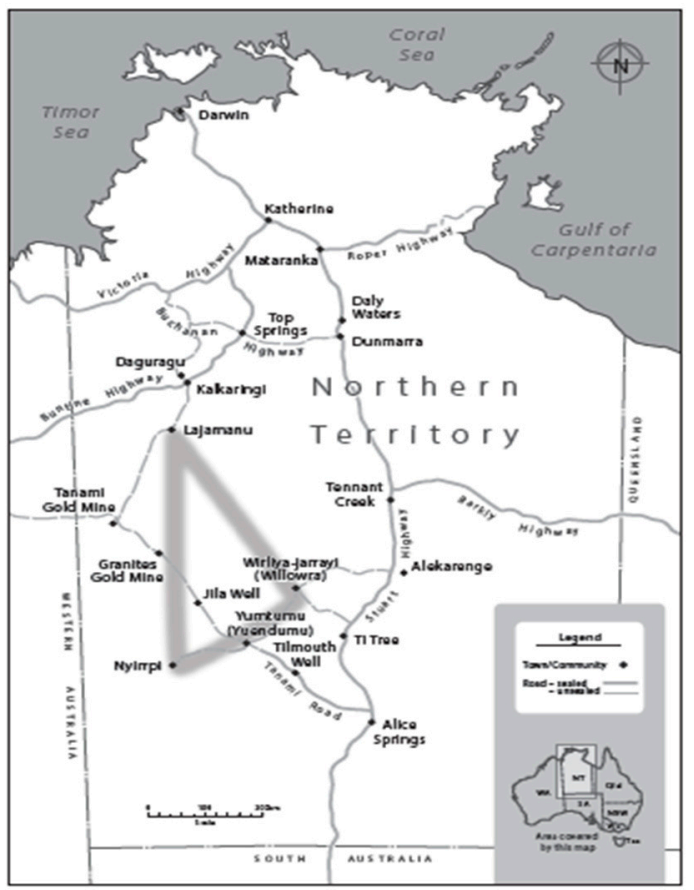

Figure 1. Map of the NT showing the Warlpiri Triangle communities (by Brenda Thornley (O'Shannessy et al. 2019b). Used with permission).

Warlpiri is a Yapa language of the Pama-Nyungan family (Laughren et al. 1996; O'Shannessy 2020b) and has been relatively well documented (see David Nash (2021) website for a comprehensive list of resources on Warlpiri language). The 1970s saw increased interest in the description of grammar and morphosyntax (Hale et al. 1995; Nash 1983, 
1986; Simpson 1983, 1991; Swartz 1985) resulting in the first typological sketch of Warlpiri grammar (Hale 1976), paving the way for community literacy workshops (Hale 1974) and production of Warlpiri dictionaries, the largest of any Australian Aboriginal language (Laughren and Nash 1983). Several major dialects of Warlpiri have been documented and variance across the four communities has been identified in terms of pronunciation and vocabulary, usually influenced by neighbouring languages (Laughren et al. 1996). In a teacher education workshop in 2001, Warlpiri educators described an "invisible boundary" separating these dialects on Warlpiri land (Northern Territory Department of Education 2001, p. 3). In conversation, people often compare varieties of Warlpiri spoken in different communities along a continuum of rampaku 'light' or pirrjirdi 'strong/heavy/hard'. The former involves more borrowing from and code-switching to English, whereas the latter characterizes the precolonial grammatical and vocabulary features of older speakers, and this 'classic Warlpiri' is viewed by Warlpiri speakers as the higher-status variety of the language (O'Shannessy 2011, p. 135; Simpson 2013). Light Warlpiri is a contact language that has emerged in Lajamanu community and systematically draws on elements of Warlpiri, Kriol and varieties of English (O'Shannessy 2005; O'Shannessy 2011).

In Yuendumu, Warlpiri is the socialising language of the home and children are exposed to English through interaction with health and education services such as the clinic, childcare, and trips to the regional towns of Alice Springs and Katherine. An increasing variety and complexity of inputs from family, teachers, youth workers, mass media and digital technologies shape their receptive and productive opportunities (Browne 2019; Kral 2012; Simpson 2013; Vaarzon-Morel 2014). Yet, recent work with children in Yuendumu has highlighted Warlpiri children's strong awareness of their multilingualism and of varieties of Warlpiri for different purposes (Browne 2019). Code-switching and language alternation between Warlpiri and varieties of English are commonplace (Bavin 1989; Bavin and Shopen 1985), though the contemporary dynamics and extent are being investigated (O'Shannessy et al. 2019b). There is evidence of an impact of English on Warlpiri language use in terms of phonology, morphology and vocabulary (see O'Shannessy 2020b and references therein). Pressures from education and employment have impacted opportunities for in-context learning of specialized vocabulary (e.g., plants, animals, traditional ceremonies and kinship quantificational terms) and language forms (Bavin 1989; Bowler 2017).

With the influence of English, the importance of maintaining Warlpiri language and the related expression of cultural sovereignty is a concern for many Warlpiri speakers, keenly aware of the threat of language loss (Disbray 2014; Holmes and Jampijinpa 2013; Musharbash 2008; Northern Territory Department of Education 2008; Pawu-Kurlpurlurnu et al. 2008; Warlpiri-patu-kurlangu-jaru 2011). Warlpiri language is viewed as an irreplaceable intellectual, social and cultural resource, as an emblem of social identity, as a means for economic participation and as a requirement of participation in kinship and cultural and/or spiritual ceremonies (Disbray et al. 2020b; Pawu-Kurlpurlurnu et al. 2008; Ross and Baarda 2017). In the specific neo-colonial context of these communities, the goal of language maintenance is understood within a history of colonial violence, subjugation and oppression (Bradley 2019; Churcher 2018; Rowse 1992; Wilson 1983) and speakers today carry the responsibility for the survival of the language (and associated knowledge) on a global scale.

\section{Warlpiri Education}

One of the domains that Warlpiri communities hold to promote intergenerational cultural and linguistic transmission and reproduction are the Warlpiri programs in community schools. These programs are viewed as a central effort in the communities' agenda for language maintenance and express educational equity, self-determination and well-being as a key rationale (Disbray 2014; McCarty and Nicholas 2014). When the first schools were established in Warlpiri communities, they were English only and Warlpiri was actively excluded (Lee et al. 2014). However, in the 1970s the Federal Government's interest in offering "primary education in Aboriginal languages" (Department of Education 1973 in Disbray 
2014, p. 1) opened up what has been described as a "period of remarkable creativity, educational engagement and innovation" (Disbray 2014, p. 1) and afforded Warlpiri communities more say in the government-run education system. Yuendumu school was one of the first schools in the Northern Territory with a bilingual program, in 1974 (Ross and Baarda 2017), and Willowra followed after grassroots community advocacy in 1976 (Vaarzon-Morel and Wafer 2017) and Lajamanu in 1982 (History of Lajamanu School Bilingual Program 1999; Patterson and Anderson 2014), although written texts for children in Warlpiri were being produced at Lajamanu school in the 1970s (p.c. Carmel O'Shannessy). Nyirrpi school, which has never officially had bilingual status, was set up after the establishment of the Nyirrpi community and collaborative community advocacy in the 1980s. The genesis of these programs demanded that Warlpiri educators "grow their own" (Smith and McPeake 2019) teachers, curricula and teaching materials, entailing enormous acquisition planning, creating of materials in Warlpiri language and preparation of language teachers (O'Grady and Hale 1974). A team of literacy production workers and linguists at the Yuendumu school-based Bilingual Resource Development Unit (BRDU) have worked with the four communities and their respective school-based literacy production centres since the 1970s to develop, disseminate and archive resources in Warlpiri language, depicting Warlpiri traditional and contemporary knowledges and experience, with hundreds of titles available (Disbray 2014, p. 137). As McCarty and Nicholas have pointed out, in general "None of these are simple, straightforward, or nonideological tasks, and all require significant investments of time, ingenuity, and human and material resources" (McCarty and Nicholas 2014). Recounts from this period reflect this complexity and effort (Devlin et al. 2017).

The Warlpiri Triangle network of educators developed out of kinship and professional ties between the four Warlpiri communities (Purdon 2010). Between 1984-89 intercommunity workshops were held to develop, among other areas, bilingual mathematics resources, and a secondary level language and culture curriculum (Disbray et al. 2018). After a hiatus in the early 1990s, in 1998 educators began the process of setting up a formal incorporated entity open to all educators and Warlpiri interested in education and learning matters, the Warlpiri-patu-kurlangu Jaru Inc. (WPkJ) with meetings held at annual Warlpiri Triangle workshops in each community (Warlpiri-patu-kurlangu-jaru 2011). The first Annual General Meeting (AGM) in 2001 was attended by over 90 Elders and educators in Lajamanu (Warlpiri-patu-kurlangu-jaru 2011). The Warlpiri Triangle workshops offer professional development for Warlpiri educators and the wider community in developing teaching materials and curriculum and song writing (Disbray and Martin 2018). These meetings have historically received funding from the NT Department of Education and participating communities and schools. For a period, contributions were also made by the Schools of Education Studies, Community Studies and General Studies of the Batchelor Institute of Indigenous Tertiary Education while they were providing teacher training to Warlpiri educators. In 2005, Warlpiri educators and traditional owners of the Newmont Tanami gold mine, set up the Warlpiri Education Training trust (WETT) to utilize royalty income to fund projects that meet Warlpiri educational aspirations such as bilingual and bicultural resources, youth leadership, training and development and intergenerational learning, independent of government initiatives (Disbray and Guenther 2017). In 2006, WETT supported the initiation of smaller planning workshops called Jinta-jarrimi (Becoming one) alternating between Wirliyajarrayi and Nyirrpi communities in terms 1, 2 and 4 (Disbray and Martin 2018). The workshops follow routine protocols involving a welcome by the host community, sharing from each school, planning for next term's curriculum theme with elders, song writing, group reading and problem solving and advocacy (Disbray 2014).

Emerging from the intergenerational work at both sets of workshops has been the creation, development and ongoing planning and elaboration of the Warlpiri Theme Cycle, a curriculum guide encompassing Warlpiri knowledges and pedagogy across 12 thematic units (Disbray and Martin 2018). All schools follow the same themes for teaching, and plan together for these in the professional development workshops. In 2018, Warlpiri communi- 
ties funded a project via the Granites Mine Affected Area Aboriginal Corporation Project (GMAAAC) to consolidate all the work by Warlpiri educators and community members into a handbook. This involved aligning the Warlpiri Theme Cycle with the Australian curriculum and achievement standards (The Australian Curriculum, Assessment, and Reporting Authority 2020), differentiating age appropriate outcomes for use by teaching teams in planning, teaching and assessment of Warlpiri in bilingual schools and those with Warlpiri Indigenous Language and Culture programs (Macdonald 2018).

There have been many systemic, institutional and local challenges to achieving community goals for education over the years in Warlpiri Triangle communities (Disbray 2014; Hall 2018). The most profound of these have been described as "the vicissitudes of the Northern Territory Education Department's ambiguous commitment, and the resultant power of individual [school] principals over the fate of the local program" (Disbray et al. 2020a, p. 3). In 2008 this ambiguity saw the introduction of the First Four Hours of English policy, which undermined the teaching of languages other than English in the bilingual programs across the NT (Devlin et al. 2017). Nevertheless, the Warlpiri Triangle schools committed to continuing Warlpiri language teaching, albeit with limited institutional support (Northern Territory Department of Education 2008). The individual trajectories of each school have also been shaped by specific community dynamics over time, but the Warlpiri Triangle network, its policy direction and curriculum documentation provide a clear guide and stable, unifying platform.

One of the key goals for Warlpiri teaching within the bilingual Warlpiri-English program is consistently articulated as developing learners with Warlpiri pirrjirdi 'strong Warlpiri' language (Northern Territory Department of Education 2012, p. 4). This raises questions of how Warlpiri pirrjirdi 'strong Warlpiri' is constructed and positioned for teaching and learning in the context of diverse and dynamic community language practices and in the context of local language-in-education management. How do Warlpiri educators individual language ideologies and collective goals of language maintenance shape the implementational spaces in schools?

\section{Materials and Methods}

Before we present the method for this study, we position ourselves as researchers and educators in accordance with Styres' (2017, p. 7) observation that, "locating oneself in relation to everything one does is one of the key foundational principles in Indigenous research contexts. The only place from which any of us can write or speak with any degree of certainty is from the position of who we are in relation to what we know". The first author, now a PhD candidate, has worked with Warlpiri educators and early childhood practitioners on first language education and governance projects in Central Australia since 2013. The second author is a Warlpiri teacher, educator-mentor and advocate currently living in the remote Warlpiri community of Nyirrpi where she was involved in starting its very first formal school. Her contributions to Warlpiri education span beyond the classroom as a founding member of the Warlpiri Education Training Trust (WETT) Advisory Committee, mentor of trainee teachers and advisor on education projects (her biography is in Anderson et al. (2018)). Both authors regularly attend Warlpiri Triangle meetings, the first author's participation being three decades shorter than the second's involvement. We were prompted to co-author this paper after co-constructing and coconducting interviews with Warlpiri teachers as part of the first author's PhD project in 2018/9 and subsequent discussions for a presentation together at the Puliima Indigenous Languages \& Technology Conference in 2019 and Macquarie University's Postgraduate Conference on Multilingualism in 2020.

This paper explores the ideological construction of Warlpiri pirrjirdi 'strong Warlpiri' as the classroom language code in five semi-structured interviews with Warlpiri educators in 2018 complemented by systematic analysis of four decades of documentation from intercommunity Warlpiri educator workshops. It aims to situate perspectives within historical discourse around maintenance of Warlpiri language in Warlpiri schools. The authors, a 
Warlpiri educator (R2) and a non-Warlpiri researcher (R1), collaborate to co-construct and conduct interviews, and analyse and interpret data. This collaboration was important to avoid colonising, misrepresenting and further silencing educator perspectives and voices (Smith 2012). We focus on teachers and draw on Community of Practice theory derived from a sociocultural perspective to explore the construction and development of identities through participation and engagement with others (Lave and Wenger 1991; Wenger 1998). This work is part of broader doctoral research taking an ethnography of communication approach (Hymes 1974; Saville-Troike 2003) to describe classroom language practices in Warlpiri classrooms at Yuendumu school that includes recordings of classroom interactions, interviews and language awareness activities with both students and teachers. Field notes also shaped interpretations for this paper. The project has obtained ethics approval from the Australian National University and the Northern Territory department of Education.

\subsection{Educator Workshop Reports and Publications}

All available education workshop reports from 1984 to 2019, comprising 16 Warlpiri Triangle reports and 19 Jinta-jarrimi reports as well as public documents by Warlpiri educators (e.g., Curriculum documents, other school Professional Development workshop reports, school policy, public statements), the grey literature formed the textual data for this paper. Warlpiri Triangle workshop reports offer privileged access into collective and individual ideas articulated by Warlpiri educators over a 40-year period, across the four communities. The workshop reports include a record of week-long meetings encompassing sharing sessions, planning, professional development opportunities, advocacy meetings, song writing, materials development and literacy workshops. The reports are compiled by a representative from the Department of Education (DoE) (a linguist, teacher-linguist or language resource officer) and include detailed minute taking from meetings, transcripts or summaries of commentary and presentations, photographs of work samples and activities. Draft reports are shared with participants for checking and comment before being finalised and disseminated to schools and literacy production centres in the communities for safekeeping and future use (Select reports published before 2001 can be accessed in the National Library Archive of Australia). While the workshops are mostly conducted in Warlpiri, and early reports reflected this usage, in recent decades the reports are either in Warlpiri with English translations or just in English. Rather than viewing these as neutral instances of teachers' positions, we acknowledge the role the representational process of text construction might play in amplifying consensus (Clifford 1986).

As in some similar contexts, this grey literature is "not widely acknowledged or disseminated through more formal channels of academic publishing and research about teacher education" (Bat and Shore 2013, p. 4). Even though a number of recent studies have drawn on the grey literature from Warlpiri professional development efforts to describe the development of the Warlpiri theme cycle (Disbray and Martin 2018), and collaborations among researchers and teachers on oral language development (Disbray et al. 2020a; O'Shannessy et al. 2019a), this body of work still remains on the margins of the NT education policy arena.

\subsection{Semi-Structured Interviews}

The authors constructed interview questions for Warlpiri educators to explore their meta-linguistic perspectives about language practices, policy and pedagogy. All Warlpiri educators at Yuendumu school were offered the opportunity to be interviewed at a time and place of their choosing. While many more expressed an interest in participating, due to timing and logistical factors, only five educators were interviewed. Three of these taught in classrooms at Yuendumu school and two were senior Warlpiri educators, retired from the classroom, working as mentors. All the teachers interviewed were grandparents or greatgrandparents of children at the school and were aged between 45-65. Their experience in the education sector ranges from 40 years to 6 years. Each teacher, except the one with 6 years' experience, had also spent time working in Warlpiri schools in other communities, 
either as teaching assistants or on the production of Warlpiri literacy resources. Three have completed tertiary qualifications in education and are, or have been, registered teachers, the other two are currently completing Diplomas in Education Support through Batchelor Institute of Indigenous Tertiary Education.

Each interview was conducted face to face for 40-60 min and audio recorded, with the participant's permission. Two were conducted by the second author and the rest by the first author alone. Participants could respond in the language they preferred, which resulted in a lot of accommodation and use of English when interviewed by the first author, whose primary language is English and who is a learner of Warlpiri. Participants were given a voucher for the local Yuendumu Nguru-Warlalja Store in acknowledgement of their time and contribution. To anonymise the respondents, each participant was assigned a code, e.g., WT1 (for a teacher) or R1 (for a researcher).

Interviews were transcribed using ELAN software (ELAN 2020; Sloetjes and Wittenburg 2008) and checked and translated with the second author, an L1 speaker of Warlpiri (see Appendix A for transcription conventions based on Jefferson (2004). Interview recordings and transcripts will be archived in AIATSIS upon completion of the PhD project. Prior to commencing analysis, a preparatory process followed steps proposed by Altheide and Schneider (1996) which included setting inclusion criteria, compiling documents and articulating areas of analysis. A coding scheme was used to select, organise and analyse emerging themes related to ideologies of language use in education and connecting these to classroom practices in both the interviews and the grey literature using NVivo software (Corbin and Strauss 2008). The Community of Practice framework was consolidated from recursively moving back and forth between the literature and the themes arising from analysis.

\section{Results}

In this section we detail our findings, first exploring the educators' constructions of Warlpiri pirrjirdi 'strong Warlpiri' language, crafting the ideological space for its use in the Warlpiri classroom. Next, we outline three ways that this ideological work mediates implementational spaces for establishing Warlpiri pirrjirdi 'strong Warlpiri' as the classroom code, (1) workshopping features of the classroom code for classroom use (2) through collaborative teaching and learning with Elders, mentors and peers, and (3) by engaging with Warlpiri texts as exemplars of Warlpiri pirrjirdi ‘strong Warlpiri'.

\subsection{Ideological Spaces: Conceptualising the Language of the Classroom}

In the context of Australian Indigenous languages, the notion of "strong language", often paired with "strong culture" is prevalent in policy discourse (e.g., Hosking et al. (2000) and media representations (e.g., Browning (2019)) tied to linguistic and cultural self-determination, resistance to the imposition of English and related erosion of linguistic and cultural knowledge. In the National Surveys of Indigenous Languages (Department of Infrastructure Transport, Regional Development, Communications et al. 2020; Marmion et al. 2014; McConvell et al. 2005) a "strong language" is measured variously by numbers of speakers, intergenerational transmission, domains of use, resourcing and status. The associated mantra, "Keeping language strong" in public discourse (e.g., media (Indigenous Literacy Foundation 2020; McKenzie 2019), policy (Central Australian Aboriginal Language Association Conference 1989; Northern Territory Board of Studies 2016) and academia (Ash et al. 2010; Hudson and McConvell 1984)) refers to a suite of efforts to promote intergenerational transmission of endangered languages. In Warlpiri education, the concept of Warlpiri pirrjirdi 'strong Warlpiri language' has been consistently used to describe the medium for teaching and learning in Warlpiri schools and a goal for Warlpiri programs since the first Warlpiri educator workshops in the 1980s (e.g., Bilingual Resource Development Unit 1987). For example, in the 1998 Warlpiri Triangle workshop, teachers outlined the history of Warlpiri programming and stated that during the bilingual program: 1982-89 "in school the children spoke Warlpiri and learned in Warlpiri, strong Warlpiri was 
spoken in the school" (Northern Territory Department of Education 1998, p. 4). The term has been used with reference to Warlpiri language with little or no mixing with English and is associated with the language spoken by the older generations (Bavin 1989; Disbray et al. 2020a; Northern Territory Department of Education 1998, 2001, 2012, 2016a, 2016c, 2017a). It has also been conceptualised as involving vocabulary and syntactic features related to pre-contact themes such as ceremony, songs, ecological terms (water, birds, animals, seasons) and relationship terms (Northern Territory Department of Education 2017a, p. 34). In 2017, at a Jinta Jarrimi workshop, educators reaffirmed its role in the school, "they need to be taught strong Warlpiri every day, the whole way through school" (Northern Territory Department of Education 2017a, p. 29).

In the interviews, Warlpiri educators distinguished between community talk and classroom language practices. They reported different ways of speaking Warlpiri in homes which they positioned against a preferred code of Warlpiri pirrjirdi 'strong Warlpiri' in schools. This perspective is captured in Example 1 where two teachers acknowledged varieties of Warlpiri spoken in different Warlpiri communities, but reserved Warlpiri pirrjirdi 'strong Warlpiri', as the code for teaching at Yuendumu school.

Example 1. English translations are provided in brackets-translated by both authors. Note transcription conventions in Appendix A- <1> xxx $<1>$ denotes overlapping speech.

WT2: yeah strongu nyayirni yangka teachimanjaku

(yeah, like one should be teaching very strong)

R2: pirrjirdi nyayirni ngula karlipa $<1>$ wangkam Warlpiri yangka<1>

(like speaking really strong there [at school])

WT2: <1>pirrjirdi Warlpiri wangkami and $<1>$

(speaking strong Warlpiri and)

R2: <2>because like karlipa nyinam yangka Lajamanurla kalu mardarni yangka <2>

(because like we are like that and in Lajamanu they have something like..)

WT2: <2>we jus <2> kajirna wangkami pidgin. <3>English jaru kujarra piya <3>

(we just .. then I speak pidgin. Like using [it] with English language)

R2: yuwayi and $<3>$ Willowrarla, Yurntumurla, Nyirrpingka $<3>$

(yes and $<3>$ in Willowra, Yuendumu, Nyirripi<3>)

WT2: yimi yangka different-differenti karlipa mardarnjarni light-wani, strong-wani but Yurntumurla yungu-ngalu-jana yangka teachiman elders strong Warlpiri

(we have our different languages, light ways of speaking, strong ways of speaking. but in Yuendumu we would like to teach strong Warlpiri with the elders)

(WT2 Interview 2018)

In Example 2, WT3 indexes her use of Warlpiri pirrjirdi 'strong Warlpiri' to her identity as a teacher and contrasts her use of Warlpiri in "normal" life. She describes Warlpiri pirrjirdi 'strong Warlpiri' as facilitating language maintenance and intergenerational transfer of cultural content such as knowledge of jukurrpa 'traditional dreaming' stories and connections to country in context. Jukurrpa is often translated as 'Dreaming' (as this teacher has done) or 'Law,' describing an ancestral past that continues in the present (for a fuller explanation of Warlpiri meaning of Jukurrpa see the article in the conversation by Jeannie Herbert Nungarrayi: https: / / theconversation.com/dreamtime-and-the-dreaming-an-introduction-20833, accessed on 31 March 2021.)

Example 2. "yuwayi ('yes') I do [talk differently in the classroom to home] ... because it's different. When I'm at work I talk to the kids, because I'm a teacher. A Warlpiri teacher for them to learn but at home its normal life for me with my own family. But anyway, with kids here [at school] it's really important for me to teach them like if they grow up they can know that what they've been taught in Warlpiri is mostly about Jukurrpa Dreamings like countrysides and where we usually take them on bush trips and country visits, ngurrju ('good') and overnight trip when we go and visit family country yuwayi ('yes') it's like exploring all the other family's country-we usually take the TOs [traditional owners]." 
(WT3 Interview 2018)

Similarly, in Example 3, WT6 indexes the way she speaks to her role as a teacher within a community of practice when she notes that she uses "teacher Warlpiri" (This was also referred to as "school Warlpiri' at a Jinta Jarrimi meeting in 2017 (p. 35)) in the school.

Example 3. "As a teacher, I use my teacher Warlpiri and I think about teaching them all the time and talking teacher way in a school".

(WT6 Interview 2019)

Teachers also commented on the children's indexing of different ways of speaking to their identities and for different purposes. WT6 noted her granddaughter's ability to speak two varieties of Warlpiri, Warlpiri and Lajamanu stail ('Light Warlpiri'). She comments on the child's ownership of the latter, insisting on speaking "my language from Lajamanu" when instructed by family members to "speak Warlpiri first" at home.

Example 4. "Yuwayi ('yes') and right now I can listen to my granddaughter little [name] saying both languages Willowra- I mean Lajamanu Stail, she sometimes only speaks English but use little bit of Warlpiri, mixed. And I- we say to her, "you should always say Warlpiri first and then little bit of English", [she responds to us] "no I'm gonna talk Engli- my language from Lajamanu."

(WT6 Interview 2019)

Those interviewed (WT1, WT3, WT5, WT6) echoed concerns raised in educator workshops (e.g., Northern Territory Department of Education 1998, 2001, 2008, 2012, 2014, 2016a, 2016b, 2016c, 2017a, 2017b) about the influence of English on everyday Warlpiri use. Contact with English was noted by educators (WT1, WT2, WT3, WT6) as having wide-ranging effects on Warlpiri language practices such as borrowing of English lexical items, English insertions in Warlpiri preverbs, errors in past tense forms (e.g., Warrkanja instead of warrkarnu 'climbed'), contractions in Warlpiri vernacular and code-switching and mixing practices (Browne, Field Notes, 8 August 2018). Terms such as 'pidgin' and 'mixed up way' were employed in discussions of changes to some children's ways of speaking Warlpiri. Individual evaluations of these changes to Warlpiri language use varied somewhat. For some these practices were strongly negatively evaluated, equated with language deterioration, but for others it was a way of speaking that "we all do" (WT1). One teacher worried that her granddaughter frequently responds to her Warlpiri questions in English (WT5 Interview 2018). Another described how she herself uses English in some situations and that she alters her way of speaking when on the phone to family in Lajamanu (WT1). The same teacher acknowledged children's autonomy in their language practices "and that's the way the kids want to be, like you know? Like talk their language ... " (WT1). While Warlpiri educators had differing levels of acceptance of the influence of English on their home language practices and of the diversity of ways of speaking Warlpiri in the community, all reserved monolingual language performances of Warlpiri pirrjirdi for classroom teaching and learning. There are strong ideologies and clear ideas about what constitutes Warlpiri pirrjirdi 'strong Warlpiri' (O'Shannessy 2020a) and these have been actively crafted and engaged with over decades of professional development and learning as a community of practice.

\subsection{Implementational Spaces}

(1) Constructing Warlpiri pirrjidi as the classroom code

Explicit articulation of the features of Warlpiri pirrjirdi 'strong Warlpiri' based on analyses of children's speech have been documented in workshop reports in 2001 and a decade later, during five professional learning cycles at workshops which focused on oral language teaching and learning between 2012-13 and 2016-17. In these workshops, educators recorded and transcribed students' retellings of stories to discuss language practices reflective of Warlpiri pirrjirdi 'strong Warlpiri' and strategies to bolster these in 
the classroom. In 2001, educators categorised features of children's speech according to ngurrju/pirrjirdi 'good'/'strong' or punku 'bad'. Correct use of suffixes, complex sentences and vocabulary were considered to be ngurrju/pirrjirdi 'good' /'strong', while using English words, omitting auxiliaries and suffixes were not (Northern Territory Department of Education 2001, pp. 11-16). Changes to children's language practices that have since been documented (O'Shannessy 2005, p. 33) such as deletion of a velar stop from the velar form of ergative and locative clitics (e.g., walya-nga for walya-ngka 'earth-LOC') were considered by teachers to be "not strong Warlpiri" (Northern Territory Department of Education 2001, p. 15). The teachers concluded that "sometimes the children use English words in their Warlpiri and the teachers think they should only use Warlpiri words" (Northern Territory Department of Education 2001, p. 13). Later in the session, the teachers examined examples of Warlpiri language in group negotiated texts co-constructed by students and teachers together and noted the importance of complex sentences in texts such as Yarla-wiri-jarlu ('The big bush potato') as exemplars of "diverse and complex Warlpiri grammar" (Northern Territory Department of Education 2001, p. 15).

Between 2012-2016, five professional learning cycles were organised to support Warlpiri educators' skills in developing students' oral language. Teachers analysed recordings of children aged 5 to 14 telling stories in Warlpiri gathered by Carmel O'Shannessy from across the four Warlpiri communities (15 children from Lajamanu, 14 from Willowra, 18 from Nyirrpi, and 24 from Yuendumu) in 2010 (Disbray et al. 2020a). Each community analysed samples of children's language to describe what children know, what they need to learn and how to teach them (a table of responses from all communities is found in Appendix B) (Disbray et al. 2020a). Again, educators from all schools agreed that children needed to learn to employ correct Warlpiri case-markers and suffixes as opposed to contracted variants and emphasised use of Warlpiri over English vocabulary terms. One group commented that students need to learn "old people's language" while another echoed the need to develop contemporary Warlpiri vocabulary for English loan words (Northern Territory Department of Education 2012). Over the course of the professional learning cycle, educators developed their analytical skills and moved from describing student errors to identifying the metalinguistic vocabulary features of Warlpiri pirrjirdi 'strong Warlpiri' and strategies for addressing these in the classroom (Disbray et al. 2020a). In doing so they developed a shared repertoire of practice for the Warlpiri program (Lave and Wenger 1991).

In the 2016 workshops, Warlpiri educators identified a number of ways to advance oral Warlpiri language such as "teachers pay attention to own speech", "talk to the students in strong Warlpiri all the time", and "gentle ways of correcting" students' language use (Northern Territory Department of Education 2016a). In interviews, teachers reported being cognisant of the way they speak in the classroom and said that they tried to avoid using English and recast English responses with Warlpiri terms as exemplified in the below interchange (Example 5). WT2 explains (using everyday Warlpiri replete with English mixing), that when a student uses the English borrowing "swimming pool" she rephrases their response with the Warlpiri verb julyurl-wantimi, 'to swim'. She believes that with regular repetition a child will learn to use the Warlpiri equivalent (Repetition was noted by Disbray et al. (2020a, p. 12) in their paper for building capacity for critical listening and analysis of Warlpiri oral language among teachers).

Example 5. WT2 yeah yangka kalu kurdu-kurdurlu pija draw-mani kalu, draw-mani kalu pija, payirni karna-jana "nyarrpa jarri ka ampuj pijangka? Nyiyanpa ampuj pija yirrarn?" an wangka kaju kurdu "ngajurna yanu swimming-poolu-kurra"

(yeah when kids draw a picture, when they draw a picture, I ask them, "what is happening in this picture? What did you draw on this picture?" And a child says to me "I went to the swimming pool)

R2: yuwayi

(yes) 
WT2: yuwayi jungarni-mani karnajana Warlpiri, "ngajurna yanu julyurl-wantinjaku” kuja instead of "swimming pool", "julyurl-wantinjaku"

(yes and I correct the Warlpiri "I went swimming" like that instead of "swimming pool", "julyurl-wantinjaku".)

R2: and pina readi- mani kalu kurdu-kurdu?

(and the kids read it again?)

WT2: yeah pina readi-mani yeah pina jungarni mani an pina-readi kajulu. Same over and over nganta yeah 'til that child get pina-jarri.

(yeah and read it again, yeah and I correct it again and read it again to me. Same over and over until the child seems to know it)

(WT2 Interview 2018)

While the educators view their role as modelling the classroom code, they also position themselves as still learning many of its features and associated vocabulary. In the next section we discuss the way that collaboration supports teachers' creation of implementational space for Warlpiri pirrjirdi 'strong Warlpiri' in the school.

\section{(2) Collaboration, cooperation and partnerships}

All interviewees described an ethic of cooperation and collaboration in the education of Warlpiri children involving a number of stakeholders, including Elders, mentors, peers, literacy production teams, non-Indigenous teachers, professional learning through workshops and team teaching. In all Warlpiri Triangle report evaluations, these collaborations are frequently noted as highlights. For example, in 2015 someone noted, "planning together was inspiring $(\ldots)$ coming together in unity in one voice gives us strength and a strong voice" (and see others (Northern Territory Department of Education 2008, 2009, 2017b)). This was exemplified in the theme of the Warlpiri Triangle workshop in 2015, which translates as 'Creating Success Together: Creating and bringing together stories and language teaching really well. We're doing it together.'

The Warlpiri educators who were interviewed positioned themselves as learners of teaching practice and of Warlpiri cultural and linguistic content. Even WT6, a highly experienced educator who emphasised independence in teaching in her description of a 'strong Warlpiri teacher', explained that this independence and confidence is fostered by continuing to learn from others including elders, mentors, the BRDU team and other professional development opportunities. There has been consistent reference in workshops throughout the decades to the importance of elders' involvement in education as teachers at home and at school, possessing knowledge about storytelling, culture, discipline, and mentoring Warlpiri teachers and strong Warlpiri language (Northern Territory Department of Education $(1998,1999,2006,2009,2011,2013,2016 c)$ and see Northern Territory Department of Education (2007) report for session explicitly articulating Elders' roles in the classroom).

In interviews, the ways the elders speak Warlpiri were described by all teachers as the authentic, prestigious form of Warlpiri. The importance of their input in children's education in classrooms and on bush trips, as well as on the teachers' own education, was emphasised. Positive value judgements were extended to the type of Warlpiri spoken by the older generations of Warlpiri speakers, the interviewees' parents, which was often described as "hard" unmixed forms of Warlpiri that do not contain English. Elders were constructed as primary sources of "authentic knowledge" (cf. Meek 2007) and their role in transmitting cultural and linguistic knowledge was acknowledged by all educators (WT1, WT2, WT3, WT5, WT6). Educators explained that they themselves are still learning the hard Warlpiri encompassing complex grammar, vocabulary and knowledge systems. For example, WT3 explained the role of elders as being "there to support and give us more information about Warlpiri things that still hidden in that long hard language that we do not really know". She described the benefits of working with Elders to develop higher-level teaching resources, giving the example of collaboration on a text about the human skeletal and digestive system at a Jinta Jarrimi workshop in Willowra in 2015 (WT3 Interview 2018). 
WT1 noted "we still learning, [we're] learners" and in the following excerpt (Example 6), WT1 positions the teachers as learners of "hard" Warlpiri language of the elders alongside the students.

Example 6. "Yuwayi nganimpa nyinami karnalu Warlpiri-patu tija? Yangka pina-pina, pina-mani karnalu jana kurdu-kurdu Warlpirirli but yangka ngula karnalu yani nganayi-kirra yangka culture trips an country visits an yangka teaching kuurlurla yangka kurdu-kurdu. Lawa still-i kalu nganpa yapa yanirni muturna-muturna manu purlka-purka. Pina-pina-mani kalu nganpa yangka maybe new words marda. Kula karnalu milya-pinyi, lawa. Manu nganimpa jalanguju stilli karnalu pina-jarrimi. Murnma-juku. Yuwayi learn-jarri karnalu yangka yirdi-wati yangka. Because yangka old people-rlulu, muturna-muturna manu purlka-purkarlu, kalu use-i-mani ngulaju old words waja nyurru-warnu patu. Yuwayi kuja-nawu karnalu do-mani nganimparluju yangkaju kula karnalu milya-pinyi nganimpa teacher-watil. Nganimpaju karnalu pina-pina-jarri murnma-juku. Yangka kurdu-kurdu ngula kalu jalangu-wan-juku kalu pina-pina-jarri kuja gen karnalu nganimpaju pina-pina jarri. Purlkangku purlka-purlkarlu muturna-muturnarlu kalu nganpa pina-pina mani"

('yes, us Warlpiri teachers. When we teach kids Warlpiri but we go to uhm to the culture trips and country visits and teaching kids in the school. The old people still come with us. They teach us things like new words maybe. We don't know them, no we don't. And we today are still learning. Yes, are learning those words. Because those old people, old women and old men use those old words, words from the past. Yes, and that's how we do it, like that. We don't know them, us teachers. We are learning still. What these little kids are learning, we are still learning too from the teaching of the old people, the old men and old women. They are teaching us')

(WT1 Interview 2018)

Professional learning opportunities such as Warlpiri Triangle and Jinta Jarrimi workshops were described by all participants as being invaluable to their professional development, reflected in this statement,

Example 7. WT2: yuwayi, yuwayi jinta-jinta-mani karlipa and yani karlipa meeting-kirra, Warlpiri Triangle, Jinta Jarrimi. Ngulangka karlipa yimi-jangka jinta-jinta-mani karlipa. Yungurlipa whole lot pina-jarrimi Warlpiri.

('Yes getting together and we go to meetings, to Warlpiri Triangle, Jinta Jarrimi. And at these [meetings] we bring our experiences together and we can all learn together about Warlpiri.)

(WT2 Interview 2018)

An example of pooling knowledge and experiences across the four communities was a session at the Warlpiri Triangle meeting in 2014 where elders and educators collaborated to document, for teaching purposes, kin terms related to spousal and sibling relationships that are no longer in everyday usage. For this session, linguist Mary Laughren played recordings made in the 1970s as an aid and prompt for discussion or as a "focus for people to remember" (Northern Territory Department of Education 2014, p. 42). Combined input from community members from four communities strengthened and enriched the documentation process.

Team teaching with Warlpiri peers and mentors was noted as an important collaborative practice for developing confidence and skills. WT3 compared increased satisfaction and outcomes whilst working with another Warlpiri teacher on their own lessons in Warlpiri to working as an assistant to the non-Warlpiri teacher in mainstream lessons. She described the building of confidence and professional learning from this role. It is interesting to note a shift in her choice of language, beginning in English to describe her role in teaching via English medium and then shifting to Warlpiri to discuss her Warlpiri experience.

Example 8. "mmm when I'm in the classroom teaching with [teacher name] in English lesson, its ok that I'm there to support [teacher name] cos we've worked together nearly 
four year in same like class from upper class to lower class teaching in red class, yellow class, blue and then orange. That's moving from younger to lower class ... to upper class and ngula-jangkaju ngurrju-nyayirni karna feel-jarri kujarna Napurrurla-kurlu, [Warlpiri educator namel-kirli warrki-jarrija jintangka. Ngularna jana jintangkajuk mardarnu ngulalparna Napurrurla nyangu ngulalpa-juk pina-ngarru-uh pina-yirri-puraja nyarrpa do-manjaku warrki. Kujarna nyangu-nyanungku ngula-jangkaju feel-jarrijarna strong-ulku jelpilki work-jarrinjaku

('and then started to feel really good when working with Napurrurla, with [name] when we worked together. When we were together I would observe Napurrula and she'd explain to me how she does the work. After seeing her teaching, I felt really confident/strong to do the work by myself.')

(WT3 Interview 2018)

In addition to the modelling from elders and mentors as communities of practice, Warlpiri educators also identified Warlpiri texts as exemplars of the features and vocabulary of Warlpiri pirrjirdi 'strong Warlpiri', discussed in the next section.

\section{(3) Engaging with Warlpiri texts}

Warlpiri literature production began in the 1970s as reference material for Warlpiri knowledge in teaching programs (Disbray 2015). In interviews, educators referred to Warlpiri texts developed by Warlpiri elders and community members as providing useful exemplars of Warlpiri pirriirdi 'strong Warlpiri', listing reference works, dictionaries, fiction, flashcards, worksheets, literacy games and readers (Browne, Fieldnotes, August-June 2018/9) (These are stored at the BRDU and many of these can be found on the Living Archive of Aboriginal Languages http:/ /laal.cdu.edu.au, accessed on 31 March 2021). One of the strategies identified in the 2016 workshops for developing strong Warlpiri skills was to "read aloud complex and advanced Warlpiri books" (Northern Territory Department of Education 2016a) as a way of increasing input that is free from English insertions. During the interviews, teachers gave numerous examples of how they utilise this rich body of textual materials to leverage learning on any topic. When WT5 was asked about the kinds of activities that are used in the classroom she explained that reading books is a way of stimulating discussion about the given Warlpiri curriculum theme in the Warlpiri Theme Cycle. For example, when teaching the theme Jaru manu rdaka-rdaka 'communication and hand signs' in 2018, she used a reference book about birds to explore ways in which they can convey information, giving the example of jiyiki 'zebra finches', which indicate water nearby or various messenger birds bringing good or bad news. She emphasised that Warlpiri texts produced specifically for a knowledge domain contain the appropriate Warlpiri terminology for that domain, much of which is not in everyday usage. She joined another educator (WT3) in describing texts as scaffolds for teachers' own language development.

Another educator in an interview referred to a jukurrpa 'dreaming' story from a place that didn't belong to her within Warlpiri culture. When asked for details about the story she explained "I can't tell you but if I have [the] book, I can" (WT1 Interview 2018). She did not have cultural authority to tell the story but using the book written and approved by people with authority contextualises the story differently and makes it accessible to a wider audience, and for learning by children. This example reveals how published stories can preserve knowledge that might not be widely accessible. Appropriate and careful consideration of the dynamics of dissemination of texts are required but can support educators to transfer knowledge to students in respectful and culturally congruent ways. The body of literature developed for the Warlpiri program ties together the knowledge and authority of elders and as reference material for teaching, contributes to the strong sense of continuity for contemporary teaching of language and content, developed by the Warlpiri Triangle network as a community of practice. 


\section{Discussion}

Analysis of the body of grey literature reveals a rich history of community engagement with questions of the role of schools in language learning and language maintenance. Over 40 years, and particularly recent decades, the concept of Warlpiri pirriirdi 'strong' language as the goal for the Warlpiri program in the school has been the topic of articulation and deep thinking among Warlpiri educators during professional development meetings. Changes to the local language ecologies from decades of contact with English have heightened the demand for "ideological clarification" regarding language maintenance activities. The professional learning around oral language development in recent years has been crucial in supporting Warlpiri educators to develop their critical analysis of students' language learning needs and strategies for addressing these (Disbray et al. 2020a). This is consistent with Kroskrity's (2009) observation that "ideological clarification" is not just periodic and once off but a process of ongoing engagement that is responsive to evolving local conditions. In interviews, teachers' personal views of changes to the local language ecologies varied somewhat, with some accepting children's ownership of new ways of speaking Warlpiri, while others expressed concerns about its deterioration. The disjunct between expressed goals of language preservation and more complex, unstated ideologies, beliefs, emotions that promote its abandonment, has been well documented (Dauenhauer and Dauenhauer 1998; Kroskrity and Field 2009; Simpson 2013). The Warlpiri example, however, shows how an intentional process of mutual engagement can address these tensions to establish a clear ideological position pertaining to what the classroom code is, its essential role in teaching and learning Warlpiri in school, and by extension, the maintenance of Warlpiri language generally. Discussion of specific teaching strategies in the workshops further supports this alignment.

As in other minority language contexts, articulation of classroom language practices by Warlpiri teachers is indexed to their role as educators (Lin 2006; Martínez et al. 2015; Palmer and Martínez 2013). The theoretical concept of Community of Practice has explanatory power in exploring how educators develop shared repertoires of practice, shared routines and ways of doing things that assist in clarifying their intentions with one another (Wenger 1998). Collaboration and partnership in teaching and learning are important themes in our analysis. The mentor-apprentice model of learning to teach and learning the language for teaching from elders and mentors is significant, particularly in the context of limited opportunities for formal training in remote communities (Chenhall et al. 2010; Lee et al. 2014). Educators expressed concerns however, about the difficulty of teaching linguistic and cultural content with the passing of the current generation of elders. They indicated the importance of literacy production centres for recording oral and written language exemplars. Recordings were also used in workshops as prompts and scaffolding for documentation. This also highlights the importance of creative and innovative pedagogies and technologies for utilising language samples in the classroom in ways that are engaging and relevant for the contemporary generation of Warlpiri students.

The Warlpiri Triangle collaboration has opened up both the ideological and implementational spaces (Hornberger 2005) for Warlpiri language to be taught in schools where they have not been consistently afforded, promoting Warlpiri knowledge, allowing for the development of Warlpiri language skills and facilitating access to the curriculum. Despite official bilingual programs in place in Warlpiri schools since the 1970s, the patchy macro level institutional and policy environment has hampered continuity of programming and necessitated the prising open of the spaces by educators and communities to create consistency and stability for ongoing program development, delivery as well as professional development of teachers. In interviews educators (e.g., WT and WT6) described times when there was simply no implementational space, "no room" (WT6) within individual schools due to macro policy factors (Devlin 2009; Hoogenraad 2001; Nicholls 2005; Simpson et al. 2009) or school-level dynamics such as unsupportive principals, community conflict or staffing shortages (History of Lajamanu School Bilingual Program 1999; Hoogenraad 2001; Ross and Baarda 2017). Nevertheless, the Warlpiri Triangle platforms afford educators 
a means to continue to creatively imagine, advocate and plan for opportunities for Warlpiri language maintenance in schools when conditions are favourable once again.

\section{Conclusions}

The example of the Warlpiri Triangle communities and their struggle to provide first language education in their schools highlights the tenacity of one speech community under enormous pressure from the hegemonic dominance of English language and institutions. When individual Warlpiri educators walk into their classrooms, they bring with them 40 years of community articulation and rearticulation of their role, its importance and the ways in which they can achieve community goals of maintaining 'strong Warlpiri language'. The Warlpiri Triangle professional development meetings have historically served as platforms for forming, restating and expanding on consensual ideologies, collaboratively and intergenerationally. Not only thus are the Warlpiri Triangle workshops key platforms for professional development, they are also arenas for collective community ideologies to be articulated and refined for practice in the classroom. We conclude with a call by an educator at a Jinta Jarrimi meeting for attention to be paid to the consistent efforts of educators at Warlpiri Triangle meetings,

“... We can't stop our language, it's strong. They nearly took that Bilingual program from us. They keep changing; we don't keep changing and they don't understand. We need to make others listen to what we are sharing at the Warlpiri meetings."

(Northern Territory Department of Education 2016b, p. 10)

Author Contributions: Conceptualization, E.B.; Formal analysis, E.B and F.G.N.; Funding acquisition, E.B.; Investigation, E.B. and F.G.N.; Methodology, E.B.; Project administration, E.B.; Validation, F.G.N.; Visualization, E.B.; Writing-original draft, E.B.; Writing-review \& editing, E.B. and F.G.N. All authors have read and agreed to the published version of the manuscript.

Funding: This research received no external funding.

Institutional Review Board Statement: The study was conducted according to the guidelines of the Declaration of Helsinki, and the Australian Institute of Aboriginal and Torres Strait Islander Studies Guidelines for Ethical Research in Australian Indigenous Studies. It has been approved by the Australian National University's Ethics Committee Protocol No. 2018/060 and the Research Subcommittee of the Northern Territory Department of Education.

Informed Consent Statement: Informed consent was obtained from all subjects involved in this study.

Data Availability Statement: The data will be archived at the Australian Institute for Aboriginal and Torres Strait Islander Studies upon completion of the PhD project.

Conflicts of Interest: The authors declare no conflict of interest. 


\section{Appendix A}

Table A1. Transcription conventions adapted from (Jefferson 2004).

\begin{tabular}{|c|c|}
\hline (.) & A dot between parentheses indicates a brief interval (between $0.02-0.8 \mathrm{~s}$ ) \\
\hline (1.5) & Numbers between parentheses indicate length of pauses in seconds and tenths of seconds. \\
\hline$=$ & $\begin{array}{l}\text { Equal signs indicate 'latching,' that is, two utterances that follow one another without any perceptible } \\
\text { pause. }\end{array}$ \\
\hline$<1></ 1>,<2></ 2>$ & $\begin{array}{l}\text { Whenever two or more utterances happen at the same time, the overlaps are marked with numbered } \\
\text { tags: }\end{array}$ \\
\hline [laughter] & Non verbal communication such as [laughter], [crying], [sighing] in square brackets \\
\hline$x \times x$ & $\mathrm{xxx}$ is used for inaudible material \\
\hline- & "em dash"-when trailing off eg He shou-he should not have come. \\
\hline$:::$ & Colons indicate stretched sound \\
\hline word & Degree sign showing word much quieter than surrounding words \\
\hline WORD & uppercase louder than surrounding speech \\
\hline (word) & parentheses is uncertain word \\
\hline$\downarrow$ & Arrows are used for marked shift in pitch up or down \\
\hline$<$ spel $></$ spel $>$ & $\begin{array}{l}\text { this tag is used to mark words or abbreviations which are spelled out by the speaker, i.e., words whose } \\
\text { constituents are pronounced as individual letters or sounds (using IPA) }\end{array}$ \\
\hline $\begin{array}{l}\text { \{contextual } \\
\text { information] }\end{array}$ & $\begin{array}{l}\text { Contextual information is added between curly brackets where it is relevant to understanding the } \\
\text { interaction }\end{array}$ \\
\hline
\end{tabular}

\section{Appendix B}

The table below is adapted from the 2001 Warlpiri Triangle workshop report by Disbray et al. (2020a, p. 8) showing strategies identified early in the professional learning cycle:

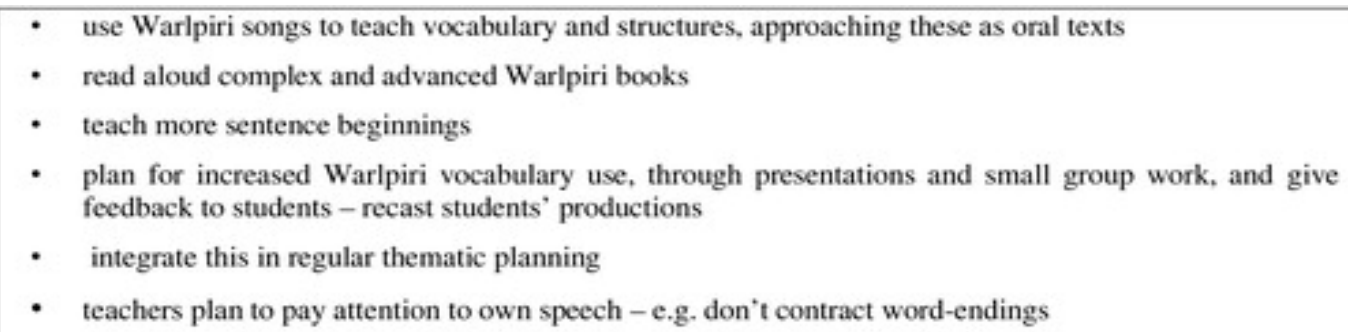

In the below table from the 2016 workshops, educators summarise educator goals to address the identified learning needs:

By the end of term 4 students will be able to:

- Orally recount events, or what they have read, and tell stories using correct phrases and whole sentences, e.g. Pirrarni ngajurna ... 'Yesterday I ...'

- Use procedural language to explain a simple process, such as making damper

- Use more strong, old Warlpiri words correctly

- Teaching teams will plan together, teach together and learn together regularly, with teacher linguist and others, to ensure students have appropriate opportunities to accelerate their learning.

- Talk to students in strong Warlpiri all the time

- Model the way to tell stories

- Do speaking and listening activities such as; singing, storytelling, listening to stories and books, listening to elders

- Prepare for assemblies, talk about pictures, listen to talking books, country visits, bush trips ${ }^{1}$

(Adapted from excerpt from 2016 Warlpiri Triangle report cited in Disbray et al. (2020a, p. 9) 


\section{References}

Altheide, David, and Christopher Schneider. 1996. Process of Qualitative Document Analysis. In Qualitative Media Analysis. Edited by David Altheide and Christopher Schneider. London: SAGE Publications, pp. 38-74. [CrossRef]

Anderson, Linda, Tarna Andrews, Fiona Gibson, Mona Kantawara, Barbara Martin, Yamurna (Nancy) Oldfield, Carolyn Windy, and Lisa Hall. 2018. We Always Stay: Stories from Seven Remarkable Aboriginal Teachers in Remote Australia. Batchelor: Batchelor Institute Press.

Aravossitas, Themistoklis, and Marianthi Oikonomakou. 2018. Professional Development of Heritage Language Instructors: Profiles, Needs, and Course Evaluation. In Handbook of Research and Practice in Heritage Language Education. Edited by Peter Trifonas and Themistoklis Aravossitas. Cham: Springer International Publishing, pp. 263-84. [CrossRef]

Ash, Anna, Pauline Hooler, Gary Williams, and Ken Walker. 2010. Maam ngawaala: Biindu ngaawa nyanggan bindaayili. Language centres: Keeping language strong. In Re-Awakening Languages: Theory and Practice in the Revitalisation of Australia's Indigenous Languages. Edited by J. Hobson, K. Lowe, S. Poetsch and M. Walsh. Sydney: Sydney University Press, pp. 106-18.

Browne, Emma. 2019. Multimodal tools for exploring communicative practices among multilingual students in remote central Australia. Babel 54: 28-33.

Baldauf, Richard, and Robert Kaplan. 2005. Language-in-Education Policy and Planning. In Handbook of Research in Second Language Teaching and Learning. Edited by E. Hinkel. London: Routledge.

Bat, Melody, and Sue Shore. 2013. Listening Differently: An Exploration of the Grey Literature on Aboriginal Teacher Education in the Top End of the Northern Territory. Review of Grey Literature Produced for the MATSITI Funded Project: "Pathways for Yolnu Teachers: Rethinking Initial Teacher Education (ITE) on Country. Available online: https:/ / www.cdu.edu.au/sites/default/files / school-education/docs/matsiti-grey-literature.pdf (accessed on 31 March 2021).

Bavin, Edith. 1989. Some lexical and morphological changes in Warlpiri. In Investigating Obsolescence: Studies in Language Contraction and Death. Edited by N. C. Dorian. Cambridge: Cambridge University Press, pp. 267-86.

Bavin, Edith, and Tim Shopen. 1985. Warlpiri and English: Languages in contact. In Australia, Meeting Place of Languages. Edited by M. Clyne. Canberra: Pacific Linguistics.

Bilingual Resource Development Unit. 1987. Warlpiri Triangle Mathematics Workshops 1985-86: Karlarlakari-Karlarlakari-kirli:Kujarnalu yirri-puraja many yirrarnu Nyurruwiyi turnu-jarrinjarla wirliyajarrayirla manu yurntumurla. The Pattern of Decimal Numeration and Its Expression in Units for Formal Measurement of Money, Length, Area, Volume and Mass. Yuendumu: BRDU.

Borko, Hilda. 2004. Professional Development and Teacher Learning: Mapping the Terrain. Educational Researcher 33: 3-15. [CrossRef]

Bowler, Margit. 2017. Quantification in Warlpiri. In Handbook of Quantifier in Natural Language. II vols. E. Keenan and D. Paperno. New York: Springer, pp. 963-94.

Bradley, Michael. 2019. Coniston. Perth: UWA Publishing.

Brenzinger, Matthias, and Patrick Heinrich. 2013. The Return of Hawaiian: Language networks of the revival movement. Current Issues in Language Planning 14: 300-16. [CrossRef]

Brown, Tasman, Grant C. Townsend, Sandra K. Pinkerton, and James R Rogers. 2011. Yuendumu and the Warlpiri Early History. In Yuenduтu. Adelaide: University of Adelaide Press, pp. 23-44. Available online: www.jstor.org/stable/10.20851/j.ctt1sq5wwx.9 (accessed on 31 March 2021).

Browning, Daniel. 2019. Strong Language: Mobile Language Team. AWAYE! with Daniel Browning. Available online: https: / / www.abc.net.au/radionational/programs/awaye/strong-language:-mobile-language-team/10759894 (accessed on 31 March 2021).

Bunte, Pamela A. 2009. You keep not listening with your ears! In Native American Language Ideologies: Beliefs, Practices, and Struggles in Indian Country. Edited by P. V. Kroskrity and M. Field. Tucson: University of Arizona Press.

Burke, Paul. 2018. An Australian Indigenous Diaspora: Warlpiri Matriarchs and the Refashioning of Tradition. Canberra: ANU Press. [CrossRef]

Central Australian Aboriginal Language Association Conference. 1989. Keeping Language Strong [Alyawarre/Pitjantjatjara/Eastern and Western Arrernte/Luritja/Warlpiri/Anmatyerre/Warumungu/Pintupi]. Alice Springs: Institute for Aboriginal Development.

Chenhall, Richard D., Kate Senior, David Cole, Teresa Cunningham, and Ciaran O'Boyle. 2010. Individual Quality of Life Among at Risk Indigenous Youth in Australia. Applied Research in Quality of Life 5: 171-83. [CrossRef]

Churcher, Millicent. 2018. Reimagining the Northern Territory Intervention: Institutional and cultural interventions into the AngloAustralian imaginary. Australian Journal of Social Issues 53: 56-70. [CrossRef]

Clifford, James. 1986. Introduction: Partial Truths. In Writing Culture: The Poetics and Politics of Ethnography. Edited by J. Clifford and G. Marcus. Berkeley: University of California Press.

Coburn, Cynthia E, and Mary Kay Stein. 2006. Communities of practice theory and the role of teacher professional community in policy implementation. In New Directions in Education Policy Implementation: Confronting Complexity. Edited by M. I. Honig. New York: State University of New York Press, pp. 25-46.

Cooper, Robert. 1989. Language Planning and Social Change. Cambridge: Cambridge University Press.

Corbin, Juliet M., and Anselm Strauss. 2008. Basics of Qualitative Research: Techniques and Procedures for Developing Grounded Theory. Los Angeles: SAGE Publications Inc. [CrossRef] 
Dauenhauer, Nora Marks, and Richard Dauenhauer. 1998. Technical, emotional, and ideological issues in reversing language shift: Examples from Southeast Alaska. In Endangered Languages: Language Loss and Community Response. Edited by L. A. Grenoble and L. J. Whaley. Cambridge: Cambridge University Press, pp. 57-98.

Department of Infrastructure Transport, Regional Development, Communications, Jacqueline Battin, Jason Lee, Douglas Marmion, Rhonda Smith, Tandee Wang, Yonatan Dinku, Janet Hunt, Francis Markham, Denise Angelo, and et al. 2020. National Indigenous Languages Report. Available online: https:/ / www.arts.gov.au/documents/national-indigenous-languages-report-document (accessed on 31 March 2021).

Devlin, Brian. 2009. Bilingual education in the Northern Territory and the continuing debate over its effectiveness and value. Paper presented at the AIATSIS Research Symposium, 'Bilingual Education in the Northern Territory, Principles, Policy and Practice', Canberra. Available online: https://www.semanticscholar.org/paper/Bilingual-education-in-the-Northern-Territory-andDevlin/f48f1236bead411f46b8942e7b1f9ca650ce6a4e (accessed on 31 March 2021).

Devlin, Brian, Samantha Disbray, and Nancy Devlin Friedman. 2017. A thematic history of bilingual education in the Northern Territory. In History of bilingual education in the Northern Territory. New York: Springer, pp. 1-10.

Disbray, Samantha. 2014. Evaluating the Bilingual Education Program in Warlpiri schools. In Language Description Informed by Theory. Amsterdam: John Benjamins Publishing Company, pp. 25-46.

Disbray, Samantha. 2015. Spaces for learning: Policy and practice for Indigenous languages in a remote context. Language and Education 30: 317-36. [CrossRef]

Disbray, Samantha, and John Guenther. 2017. Review, Assessment and Development of Future Options for the Warlpiri Education and Training Trust (WETT) and its Programs. Available online: https://www.clc.org.au/files/pdf/WETT-review-report-2017.pdf (accessed on 31 March 2021).

Disbray, Samantha, and Barbara Martin. 2018. Curriculum as Knowledge System: The Warlpiri Theme Cycle. In Language Practices of Indigenous Children and Youth: The Transition from Home to School. Edited by G. Wigglesworth, J. Simpson and J. Vaughan. London: Palgrave Macmillan UK, pp. 23-48.

Disbray, Samantha, Gretel Macdonald, and Barbara Martin. 2018. The Warlpiri Triangle Workshops E Jinta Jarrimi (Becoming One) for Warlpiri Educators in NT Bilingual Education Programs. Adelaide: Paper presented at the Australian Lingustics Society (ALS).

Disbray, Samantha, Carmel O'Shannessy, Gretel MacDonald, and Barbara Martin. 2020a. Talking together: How language documentation and teaching practice support oral language development in bilingual education programs. International Journal of Bilingual Education and Bilingualism, 1-16.

Disbray, Samantha, Rosemary Plummer, and Barbara Martin. 2020b. Languages Ideologies and Practice From the Land and the Classroom. The Modern Language Journal 104: 519-25. [CrossRef]

ELAN. 2020. ELAN [Computer software]. Nijmegen: Max Planck Institute for Psycholinguistics: The Language Archive. Available online: https: / / archive.mpi.nl/tla/elan (accessed on 31 March 2021).

Gallucci, Chrysan. 2003. Communities of practice and the mediation of teachers' response to standards-based reform. Education Policy Analysis Archives 11. [CrossRef]

Hale, Kenneth L. 1974. Warlpiri Primer. 8 Lessons. Yuendumu: BRDU.

Hale, Kenneth L. 1976. Typological sketch of Warlpiri. Cambridge: MIT.

Hale, Kenneth L., Mary Laughren, and Jane Simpson. 1995. Warlpiri. In An International Handbook of Contemporary Research. 2 vols. Edited by J. Jacobs, A. von Stechow, W. Sternefeld and T. Vennemann. Berlin: Walter de Gruyter, pp. 1430-49.

Hall, Lisa. 2018. Not looking at us level: Systemic barriers faced by Aboriginal teachers in remote communities in Central Australia. Journal of Critical Race Inquiry 5.

Henne-Ochoa, Richard, Emma Elliott-Groves, Barbra A Meek, and Barbara Rogoff. 2020. Pathways Forward for Indigenous Language Reclamation: Engaging Indigenous Epistemology and Learning by Observing and Pitching in to Family and Community Endeavors. The Modern Language Journal 104: 481-93. [CrossRef]

Hill, Jane, and Kenneth Hill. 1986. Speaking Mexicano: Dynamics of Linguistic Syncretism in Central Mexico. Tucson: University of Arizona Press.

Hirvonen, Vuokko. 2008. 'Out on the fells, I feel like a Sámi': Is There Linguistic and Cultural Equality in the Sámi School? In Can Schools Save Indigenous Languages? Policy and Practice on Four Continents. Edited by N. Hornberger. London: Palgrave Macmillan UK, pp. 15-41.

History of Lajamanu School Bilingual Program. 1999. Ngoonjook Journal of Australian Indigenous Issues 51-54. Available online: https:/ / search.informit.org/doi/epdf/10.3316/informit.964283137322457 (accessed on 31 January 2021).

Holmes, Miles, and Wanta Jampijinpa. 2013. Law for Country: The Structure of Warlpiri Ecological Knowledge and Its Application to Natural Resource Management and Ecosystem Stewardship. Ecology and Society 18. [CrossRef]

Hoogenraad, Robert. 2001. Critical reflections on the history of bilingual education in Central Australia. In Forty years on: Ken Hale and Australian Languages. Edited by D. N. Jane Simpson, Mary Laughren and P. A. a. B. Alpher. Canberra: The Australian National University.

Hornberger, Nancy. 2002. Multilingual Language Policies and the Continua of Biliteracy: An Ecological Approach. Language Policy 1: 27-51. [CrossRef]

Hornberger, Nancy. 2005. Opening and Filling up Implementational and Ideological Spaces in Heritage Language Education. The Modern Language Journal 89: 605-9. 
Hornberger, Nancy H., and David Cassels Johnson. 2007. Slicing the onion ethnographically: Layers and spaces in multilingual language education policy and practice. TESOL Quarterly 41: 509-32. [CrossRef]

Hornberger, Nancy, Ofelia García, Tove Skutnabb-Kangas, and Maria E. Torres-Guzman. 2006. Imagining Multilingual Schools: Languages in Education and Glocalization. Bristol: Multilingual Matters.

Hosking, Diane, Tony Lonsdale, Jakelin Troy, and Micheal Walsh. 2000. Strong Language, Strong Culture: New South Wales Strategic Language Study. Canberra: Australian Institute for Aboriginal \& Torres Strait Islander Studies.

Hudson, Joyce, and Patrick McConvell. 1984. Keeping Language Strong: Report of the Pilot Study for the Kimberley Language Resource Centre. Broome: Kimberley Language Resource Centre.

Hult, Francis M. 2010. Analysis of language policy discourses across the scales of space and time. International Journal of the Sociology of Language 2010: 7-24. [CrossRef]

Hymes, Dell. 1974. Foundations in Sociolinguistics: An Ethnographic Approach. Philadelphia: University of Pennsylvania Press.

Indigenous Literacy Foundation. 2020. Keeping Arrernte Language and Culture Strong. Available online: https://www. indigenousliteracyfoundation.org.au/news-events/keeping-arrernte-language-and-culture-strong (accessed on 31 January 2021).

Jefferson, Gail. 2004. Glossary of transcript symbols with an introduction. In Conversation Analysis: Studies from the First Generation. Edited by G. Lerner. Amsterdam: John Benjamins, pp. 13-31.

Johnson, David Cassels. 2010. Implementational and Ideological Spaces in Bilingual Education Language Policy. International Journal of Bilingual Education and Bilingualism 13: 61-79. [CrossRef]

Kral, Inge. 2012. Talk, Text and Technology: Literacy and Social Practice in a Remote Indigenous Community. Bristol: Multilingual Matters. [CrossRef]

Kroskrity, Paul V. 2005. Language Ideologies. Oxford: Blackwell Publishing Ltd., pp. 496-517.

Kroskrity, Paul V. 2009. Language Renewal as Sites of Language Ideological Struggle The Need for "Ideological Clarification". In Indigenous Language Revitalization: Encouragement, Guidance \& Lessons Learned. Edited by J. Reyhner and L. Lockard. Flagstaff: North Arizona University, pp. 71-83.

Kroskrity, Paul V. 2018. On recognizing persistence in the Indigenous language ideologies of multilingualism in two Native American Communities. Language \& Communication 62: 133-44.

Kroskrity, Paul V., and Margaret Field. 2009. Native American Language Ideologies: Beliefs, Practices and Struggles in Indian Country. Tucson: University of Arizona Press.

Lane, Pia, James Costa, and Haley De Korne. 2017. Standardizing Minority Languages Competing Ideologies of Authority and Authenticity in the Global Periphery. New York: Routledge.

Laughren, Mary, and David Nash. 1983. Warlpiri Dictionary Project: Aims, method, organisation and problems of definition. Papers in Australian Linguistics no. 15: Australian Aboriginal Lexicography 0: 109-33.

Laughren, Mary Napaljarri, Robert Hoogenraad, Kenneth L. Hale, and Robin Japanangka Granites. 1996. A Learner's Guide to Warlpiri: Tape Course for Beginners: Wangkamirlipa Warlpiriki. Alice Springs: IAD Press.

Lave, Jean, and Etienne Wenger. 1991. Situated Learning: Legitimate Peripheral Participation. Cambridge/New York: Cambridge University Press.

Lee, Penny, Lyn Fasoli, Lysbeth Ford, Peter Stephenson, and Dennis McInerney. 2014. Indigenous Kids and Schooling in the Northern Territory: An Introductory Overview and Brief History of Aboriginal Education in the Northern Territory. Batchelor: Batchelor Press.

Lin, Angel. 2006. Beyond Linguistic Purism in Language-in-education Policy and Practice: Exploring Bilingual Pedagogies in a Hong Kong Science Classroom. Language and Education 20: 287-305. [CrossRef]

Liu, Yongcan, and Michael Evans. 2016. Multilingualism as legitimate shared repertoires in school communities of practice: Students' and teachers' discursive constructions of languages in two schools in England. Cambridge Journal of Education 46: 553-68. [CrossRef]

Macdonald, Gretel. 2018. Warlpiri Theme Cycle Project Description (Draft vers March 2018). Yuendumu: Bilingual Resource Development Unit, BRDU.

Makihara, Miki, and Bambi B. Shieffelin. 2007. Consequences of Contact: Language Ideologies and Sociocultural Transformations in Pacific Societies. Oxford: Oxford University Press.

Marika, Rarriwuy, Yalmay Yunupingu, Raymattja Marika-Mununggiritj, and Samantha Muller. 2009. Leaching the poison-The importance of process and partnership in working with Yolngu. Journal of Rural Studies 25: 404-13. [CrossRef]

Marlow, Patrick E., and Sabine Siekmann. 2013. Prologue: Community of Practice. In Communities of Practice An Alaskan Native Model for Language Teaching and Learning. Edited by P. E. Marlow and S. Siekmann. Tucson: University of Arizona Press, Available online: http:/ / www.jstor.org/stable/j.ctt183gz0b (accessed on 31 January 2021).

Marmion, Doug, Kazuko Obata, and Jakelin Troy. 2014. Community, Identity, Wellbeing: The Report of the Second National Indigenous Languages Survey. Canberra: Australian Institute of Aboriginal and Torres Strait Islander Studies.

Martin, Barbara, and Nancy Oldfield. 2000. 'Warlpiri'. In Strong Voices. Edited by K. Gillespie, D. Hartman and R. Watt. Batchelor: Batchelor Institute Press.

Martínez, Ramón Antonio, Michiko Hikida, and Leah Durán. 2015. Unpacking Ideologies of Linguistic Purism: How Dual Language Teachers Make Sense of Everyday Translanguaging. International Multilingual Research Journal 9: 26-42. [CrossRef] 
May, Stephen, and Richard Hill. 2005. Māori-medium Education: Current Issues and Challenges. International Journal of Bilingualism and Bilingual Education 8: 377. [CrossRef]

McCarty, Teresa L., and Sheilah E. Nicholas. 2014. Reclaiming Indigenous Languages: A Reconsideration of the Roles and Responsibilities of Schools. Review of Research in Education 38: 106-36. Available online: http:/ / www.jstor.org/stable/43284064 (accessed on 31 March 2021). [CrossRef]

McConvell, Patrick, Doug Marmion, and Sally McNicol. 2005. National Indigenous Languages Survey Report. Canberra: Australian Institute of Aboriginal and Torres Strait Islander Studies.

McKenzie, Vincent. 2019. Education is the Key to Keeping Bardi Language and Culture Strong [Press Release]. Available online: https:/ / www.abc.net.au/everyday/education-is-the-key-to-keeping-bardi-language-culture-strong/11271482 (accessed on 31 March 2021).

McMahon, Kathy, and Fran Murray. 1999. Bilingual education: Looking for the big picture. Ngoonjook, 25-41. Available online: https: / / search.informit.org/doi/epdf/10.3316/informit.964227238408682 (accessed on 31 March 2021).

McPake, Joanna, Wilson McLeod, Fiona O’Hanlon, Giovanna Fassetta, and Mona Wilson. 2017. Professional development programmes for teachers moving from majority to minoritised language medium education: Lessons from a comparative study. Language Policy 16: 79-105. [CrossRef]

Meek, Barbra. 2007. Respecting the Language of Elders: Ideological Shift and Linguistic Discontinuity in a Northern Athapascan Community. Journal of Linguistic Anthropology 17: 23-43. [CrossRef]

Menken, Kate, and Ofelia García. 2010. Negotiating Language Education Policies: Educators as Policymakers. New York: Routledge.

Minutjukur, Makinti, Valerie Patterson, Sharon Anderson, Fiona Gibson, Maisie Kitson, Barbara Martin, Valerie Martin, Hamilton Morrison, Nancy Oldfield, Serena Shannon, and et al. 2014. Voices from the red dirt on education. Journal of Australian Indigenous Issues 17: 158-63.

Musharbash, Yasmine. 2008. Yuendumu Everyday: Contemporary Life in Remote Aboriginal Australia. Canberra: Aboriginal Studies Press, Available online: https:/ / search.informit.org/doi/10.3316/informit.9780855756611 (accessed on 31 March 2021).

Nash, David. 1983. TESL* AND WARLPIRI CHILDREN Understanding Warlpiri children's problems in learning to speak English. N.T. Bilingual Education Newsletter 1 47: 6-24.

Nash, David. 1986. Topics in Warlpiri Grammar. New York/London: Garland.

Nash, David. 2021. References about Warlpiri Language (Including Sign Language) or References in Linguistics Works-Published and Unpublished. Available online: http:/ / www.anu.edu.au/linguistics/nash/aust/wlp/wlp-lx-ref.html (accessed on 21 March 2021).

Nevins, M Eleanor. 2004. Learning to listen: Confronting two meanings of language loss in the contemporary White Mountain Apache speech community. Journal of Linguistic Anthropology 14: 269-88. [CrossRef]

Nicholls, Christine. 2005. Death by a Thousand Cuts: Indigenous Language Bilingual Education Programmes in the Northern Territory of Australia, 1972-98. International Journal of Bilingual Education and Bilingualism 8: 160-77. [CrossRef]

Northern Territory Board of Studies. 2016. Keeping Indigenous Languages and Cultures Strong- a Basis for Policy for the Teaching of Indigenous Languages and Cultures in Schools in the NT. Darwin. Available online: https://education.nt.gov.au/_data/assets/ pdf_file/0012/413202/Policy_Keeping-Indigenous-Languages-and-Cultures-Strong-Document_web_updated.pdf (accessed on 31 March 2021).

Northern Territory Department of Education. 1998. Warlpiri Triangle Workshop Report (Lajamanu School). Alice Springs: Northern Territory Department of Education.

Northern Territory Department of Education. 1999. Warlpiri Triangle Workshop Report (Willowra School). Alice Springs: Northern Territory Government.

Northern Territory Department of Education. 2001. Warlpiri Triangle Workshop Report (Lajamanu School). Alice Springs: Northern Territory Department of Education.

Northern Territory Department of Education. 2006. Warlpiri Triangle Workshop Report (Yuendumu School). Alice Springs: Northern Territory Department of Education.

Northern Territory Department of Education. 2007. Warlpiri Triangle Workshop Report (Willowra School). Alice Springs: Northern Territory Department of Education.

Northern Territory Department of Education. 2008. Warlpiri Triangle Workshop Report (Lajamanu School). Alice Springs: Northern Territory Department of Education.

Northern Territory Department of Education. 2009. Warlpiri Triangle Workshop Report (Yuendumu School). Alice Springs: Northern Territory Department of Education.

Northern Territory department of Education. 2011. Warlpiri Triangle Workshop Report (Yuendumu School). Alice Springs: Northern Territory Department of Education.

Northern Territory Department of Education. 2012. Warlpiri Triangle Workshop Report (Lajamanu School). Alice Springs: Northern Territory Department of Education.

Northern Territory Department of Education. 2013. Warlpiri Triangle Workshop Report (Yuendumu School). Alice Springs: Northern Territory Department of Education.

Northern Territory Department of Education. 2014. Warlpiri Triangle Workshop Report (Lajamanu School). Alice Springs: Northern Territory Department of Education. 
Northern Territory Department of Education. 2016a. Jinta Jarrimi Term 1 Workshop Report (Yuendumu School). Alice Springs: Northern Territory Department of Education.

Northern Territory Department of Education. 2016b. Jinta Jarrimi Workshop Report Term 2. Alice Springs: Northern Territory Department of Education.

Northern Territory Department of Education. 2016c. Warlpiri Triangle Workshop Report (Lajamanu School). Alice Springs: Northern Territory Department of Education.

Northern Territory Department of Education. 2017a. Jinta Jarrimi Workshop Report Term 1 (Yuendumu School). Alice Springs: Northern Territory Department of Education.

Northern Territory Department of Education. 2017b. Warlpiri Triangle Workshop Report (Yuendumu School). Alice Springs: Northern Territory Department of Education.

O'Grady, Geoff, and Kenneth L. Hale. 1974. Recommendations Concerning Bilingual Education in the Northern Territory. (Parliamentary Paper No. 329). Canberra: The Government Printer of Australia.

O'Shannessy, Carmel. 2005. Light Warlpiri: A New Language. Australian Journal of Linguistics 25: 31-57. [CrossRef]

O'Shannessy, Carmel. 2011. Competition between word order and case-marking in interpreting grammatical relations: A case study in multilingual acquisition. Journal of Child Language 38: 763-92. [CrossRef]

O'Shannessy, Carmel. 2012. The Role of Codeswitched Imput to Children in the Origin of a New Mixed Language. Linguistics 50: 305. [CrossRef]

O'Shannessy, Carmel. 2019. Why do children lead contact-induced language change in some contexts but not others? In Language Contact, Continuity and Change in the Genesis of Modern Hebrew. Edited by Edit Doron, Malka Rappaport Hovav, Yael Reshef and Moshe Taube. Amsterdam: John Benjamins Publishing Company, pp. 321-35.

O'Shannessy, Carmel. 2020a. How ordinary child language acquisition processes can lead to the unusual outcome of a mixed language. The International Journal of Bilingualism.

O'Shannessy, Carmel. 2020b. Language Contact in Warlpiri and Light Warlpiri. In The Oxford Handbook of Language Contact. Edited by A. P. Grant. Oxford: Oxford University Press.

O'Shannessy, Carmel, Kristen Culhane, Siva Kalyan, and Emma Browne. 2019a. Language maintenance and change in morphophonology in four Warlpiri communities. Paper presented at the Annual Conference of the Australian Linguistic Society, Macquarie University, Sydney, NSW, Australia, December 11-13.

O'Shannessy, Carmel, Samantha Disbray, Barbara Martin, and Gretel Macdonald. 2019b. (Re)turning research into pedagogical practice: A case study of translational language research in Warlpiri. In Archival returns: Central Australia and beyond: LDEC Special Publication. Edited by L. Barwick, J. Green and P. Vaarzon-Morel. 18 vols. Honolulu/Sydney: University of Hawaii Press \& Sydney University Press, pp. 139-51. Available online: http:/ /nflrc.hawaii.edu/ldc/sp-18/ (accessed on 31 March 2021).

Paciotto, Carla. 2004. Language Policy, Indigenous Languages and the Village School: A Study of Bilingual Education for the Tarahumara of Northern Mexico. International Journal of Bilingual Education and Bilingualism 7: 529-48. [CrossRef]

Paciotto, Carla. 2010. Language and Literacy Planning and Local Contexts: The Case of a Raramuri Community. Anthropology and Education Quarterly 41: 161-80. [CrossRef]

Palmer, Deborah. 2011. The Discourse of Transition: Teachers' Language Ideologies Within Transitional Bilingual Education Programs. International Multilingual Research Journal 5: 103-22. [CrossRef]

Palmer, Deborah, and Ramón Antonio Martínez. 2013. Teacher Agency in Bilingual Spaces: A Fresh Look at Preparing Teachers to Educate Latina/o Bilingual Children. Review of Research in Education 37: 269-97. [CrossRef]

Patterson, Valerie, and Sharon Anderson. 2014. Focus on Development and Initiative: Warlpiri Education and Training Trust-Lajamanu Community (Video). Garma Festival of Traditional Cultures. Available online: https://www.youtube.com/watch?v=fdCboHjkk5 w (accessed on 31 March 2021).

Pawu-Kurlpurlurnu, Steven, Miles Holmes, and Lance Box. 2008. Ngurra-Kurlu: A Way of Working with Warlpiri People. Available online: http:/ / www.nintione.com.au/resource/DKCRC-Report-41-Ngurra-kurlu.pdf (accessed on 31 March 2021).

Purdie, Nola, Tracey Frigo, Clare Ozolins, Geoff Noblett, Nick Thieberger, and Janet Sharp. 2008. Indigenous Languages Programmes in Australian Schools-A Way Forward. Available online: https://research.acer.edu.au/indigenous_education/18 (accessed on 31 March 2021).

Purdon, Ailsa. 2010. Living in the mainstream. Ngoonjook Journal of Australian Indigenous Issues, 31-43. Available online: http: //eprints.batchelor.edu.au/id/eprint/250 (accessed on 31 March 2021).

Ricento, Thomas. 2000. Historical and theoretical perspectives in language policy and planning. Journal of Sociolinguistics 4: 196-213. [CrossRef]

Ricento, Thomas, and Nancy Hornberger. 1996. Unpeeling the Onion: Language Planning and Policy and the ELT Professional. TESOL Quarterly 30: 401-27. [CrossRef]

Ross, Tess, and Wendy Baarda. 2017. Starting Out at Yuendumu School-Teaching in Our Own Language. In History of Bilingual Education in the Northern Territory: People, Programs, Policies. Edited by B. Devlin, S. Disbray and N. Devlin Friedman. Singapore: Springer, pp. 247-57.

Rowse, Tim. 1992. Strehlow's Strap: Functionalism and Historicism in a colonial ethnography. Journal of Australian Studies 16: 88-103. [CrossRef]

Saville-Troike, Muriel. 2003. The Ethnography of Communication: An Introduction. 3 vols. Hoboken: John Wiley \& Sons, Incorporated. 
Silverstein, Michael. 1979. Language structure and linguistic ideology. In The Elements: A Parasession on Linguistic Units and Levels. Edited by P. R. Cline, W. Hanks and C. Hofbauer. Chicago: Chicago Linguistic Society, pp. 193-247.

Simpson, Jane Helen. 1983. Aspects of Warlpiri Morphology and Syntax. Cambridge: Massachusetts Institute of Technology.

Simpson, Jane Helen. 1991. Warlpiri Morpho-Syntax: A Lexicalist Approach. 23 vols. Dordrecht/Boston: Kluwer Academic.

Simpson, Jane Helen. 2013. What's done and what's said: Language attitudes, public language activities and everyday talk in the Northern Territory of Australia. Journal of Multilingual and Multicultural Development 34: 383-98. [CrossRef]

Simpson, Jane Helen, and Gillian Wigglesworth. 2008. Children's Language and Multilingualism: Indigenous Language Use at Home and School. London: Continuum.

Simpson, Jane Helen, Josephine Caffery, and Patrick McConvell. 2009. Gaps in Australia's Indigenous Language Policy: Dismantling Bilingual Education in the Northern Territory. Available online: https:/ /aiatsis.gov.au/publication/35378 (accessed on 31 March 2021).

Sloetjes, H., and P. Wittenburg. 2008. Annotation by category-ELAN and ISO DCR. Paper presented at the Proceedings of the 6th International Conference on Language Resources and Evaluation. Available online: http://www.lrec-conf.org/proceedings/ lrec2008/pdf/208_paper.pdf (accessed on 31 March 2021).

Smith, Linda Tuhiwai. 2012. Decolonizing Methodologies: Research and Indigenous Peoples, 2nd ed. London: Zed Books.

Smith, Sue Erica, and Tess McPeake. 2019. Growing our own: Indigenous Education on Country. Learning Communities: International Journal of Learning in Social Contexts 25. Available online: https:/ /www.cdu.edu.au/sites/default/files/the-northern-institute/ learningcommunities_number25_online.pdf (accessed on 31 March 2021).

Spolsky, Bernard. 2004. Language Policy. Cambridge: Cambridge University Press.

Spolsky, Bernard, and Nancy Hornberger. 2008. Can Schools Save Indigenous Languages? Policy and Practice on Four Continents. London: Palgrave Macmillan UK.

Styres, Sandra D. 2017. Pathways for Remembering and Recognizing Indigenous thought in Education: Philosophies of Iethi'nihstenha Ohwentsia'kekha (Land). Toronto: University of Toronto Press.

Swartz, Stephen M. 1985. Pragmatic structure and word order in Warlpiri. Pacific Linguistics. Series A. Occasional Papers. pp. 151-66. Available online: http:/ / sealang.net/archives/pl/pdf/PL-A71.151.pdf (accessed on 1 April 2021).

The Australian Curriculum, Assessment, and Reporting Authority. 2020. Australian Curriculum. Available online: https://www. australiancurriculum.edu.au (accessed on 31 March 2021).

Truscott, Adriano, and Ian Malcolm. 2010. Closing the policy-practice gap: Making Indigenous language policy more than empty rhetoric. In Re-Awakening Languages: Theory Practice in the Revitalisation of Australia's Indigenous Languages. Sydney: Sydney University Press, pp. 6-10. Available online: http:/ / hdl.handle.net/2123/6949 (accessed on 31 March 2021).

Vaarzon-Morel, Petronella. 2014. Pointing the Phone: Transforming Technologies and Social Relations among Warlpiri. The Australian Journal of Anthropology 25. [CrossRef]

Vaarzon-Morel, Petronella, and Jim Wafer. 2017. Bilingual Time at Willowra: The beginnings of a community-initiated program, 1976-77. In History of Bilingual Education in the Northern Territory: People, Programs and Policies. Edited by B. Devlin, S. Disbray and N. Devlin Friedman. Singapore: Springer Publishing, pp. 35-48.

Varghese, Manka M. 2008. Using Cultural Models to Unravel How Bilingual Teachers Enact Language Policies. Language and Education 22: 289-306. [CrossRef]

Warlpiri-patu-kurlangu-jaru. 2011. Submission 121 to the House of Representatives Standing Committee on Aboriginal and Torres Strait Islander Affairs: National Inquiry “Language Learning in Indigenous Communities”. Available online: https://www.aph.gov.au/ parliamentary_business/committees/house_of_representatives_committees?url=atsia/languages2/subs/sub121.pdf (accessed on 31 March 2021).

Wenger, Etienne. 1998. Communities of Practice: Learning, Meaning and Identity. Cambridge: Cambridge University Press.

Wilson, A. 1983. Oral History of the Coniston Massacre'(Audiotape). Alice Springs: Central Australian Aboriginal Media Association.

Wyman, Leisy, Patrick Marlow, Ciquyaq Fannie Andrew, Gayle Miller, Cikigaq Rachel Nicholai, and Yurrliq Nita Rearden. 2010. High stakes testing, bilingual education and language endangerment: A Yup'ik example. International Journal of Bilingual Education and Bilingualism 13: 701-21. [CrossRef] 